\title{
Review
}

\section{MPTP Mouse Models of Parkinson's Disease: An Update}

\author{
Gloria E. Meredith ${ }^{\mathrm{a}, *}$ and David J. Rademacher ${ }^{\mathrm{b}}$ \\ ${ }^{a}$ Department of Pharmaceutical Sciences, College of Pharmacy, Rosalind Franklin University of Medicine \\ and Science, IL, USA \\ ${ }^{\mathrm{b}}$ Department of Cellular and Molecular Pharmacology, Chicago Medical School, Rosalind Franklin \\ University of Medicine and Science, IL, USA
}

\begin{abstract}
Among the most widely used models of Parkinson's disease (PD) are those that employ toxins, especially 1-methyl4-phenyl-1,2,3,6-tetrahydropyridine (MPTP). Depending on the protocol used, MPTP yields large variations in nigral cell loss, striatal dopamine loss and behavioral deficits. Motor deficits do not fully replicate those seen in PD. Nonetheless, MPTP mouse models mimic many aspects of the disease and are therefore important tools for understanding PD. In this review, we will discuss the ability of MPTP mouse models to replicate the pathophysiology of PD, the mechanisms of MPTP-induced neurotoxicity, strain differences in susceptibility to MPTP, and the models' roles in testing therapeutic approaches.
\end{abstract}

Keywords: substantia nigra, dopamine, C57/BL mouse, grid test, hydropyridine, open field, rotarod

Parkinson's disease (PD) is a progressive neurodegenerative disease that has no cure. Developing animal models of this disease has been challenging. Despite numerous efforts to develop progressive toxic protocols in mice, few fully reflect the hallmarks of the disease. Indeed, no model fully recapitulates the progressive behavioral deterioration, advancing pathology with age, or fluctuations in motor function. The extent to which they reproduce many hallmarks of PD and the mechanisms at work in the sporadic forms of the disease vary greatly. Mouse models using 1-methyl-4phenyl-1,2,3,6-tetrahydropyridine (MPTP) are among the most widely used. The number of original papers and reviews that have been written on these models has steadily increased over the past 20 years (Fig. 1). MPTP mouse models have shed light on the pathophys-

\footnotetext{
*Correspondence to: Gloria E. Meredith, Department of Pharmaceutical Sciences, Rosalind Franklin University of Medicine and Science, 3333 Green Bay Road, North Chicago, IL 60064, USA. Tel.: +1 847578 3270; Fax: +1 847775 6586; E-mail: gloria. meredith@rosalindfranklin.edu.
}

iology as well as some of the causes of the disease. More importantly, they have provided investigators with model platforms for testing symptomatic and neuroprotective drugs. This review will focus on the use of MPTP in rodents and how these models have advanced our understanding of this debilitating disease.

\section{MPTP AND ITS METABOLITES}

Structurally, the toxin, MPTP, resembles a number of known environmental compounds, including herbicides such as paraquat [1] and the garden insecticide/fish toxin, rotenone [2]; both have been shown to induce dopamine (DA) neuron degeneration [3-6]. MPTP was first discovered by a chemistry student in 1976, who was trying to synthesize a synthetic heroin, but instead produced MPTP, which kills dopaminergic (DAergic) neurons [7]. Others, addicted to heroin, replicated this mistake in the early $1980 \mathrm{~s}$ and developed severe PD-like symptoms. Dr. Langston, who treated many of these patients, recognized the poten- 


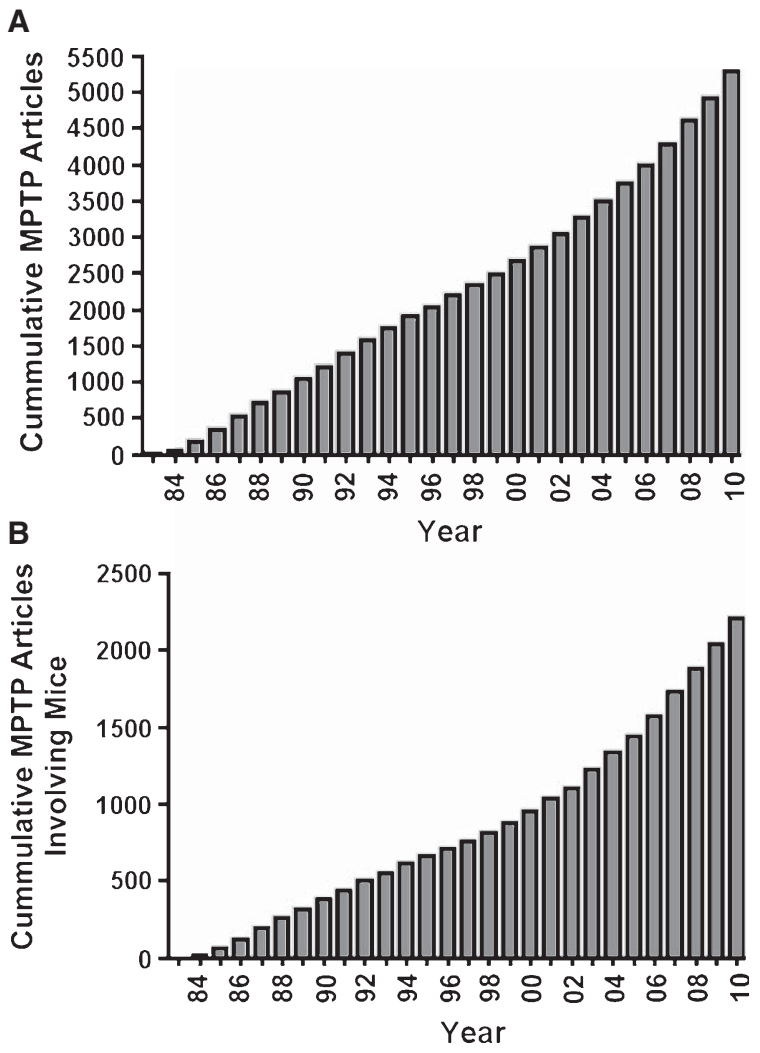

Fig. 1. Diagrams indicating estimates of total number of papers produced involving (A) MPTP and (B) MPTP administered only to mice.

tial of this toxin for creating a valid disease model [8]. He and colleagues soon identified the effects of MPTP administration in non-human primates and described the impairments that resembled the motor disabilities of idiopathic PD [8]. In 1986, Sonsalla and Heikkila [9] showed that MPTP could have many of the same effects in mice.

MPTP is highly lipophilic and easily crosses the blood brain barrier, where it binds mainly in astrocyte lysosomes [10], and there is general agreement that astrocytes convert MPTP to its toxic metabolite, the 1methyl-4-phenylpyridinium (MPP+) ion (but see [11]). Systemic administration of MPP+ does not damage central DAergic neurons, because it does not readily cross the blood brain barrier due to its charge. However, its direct infusion into the brain effectively destroys much of the DAergic nigrostriatal pathway [12]. MPP+ is an excellent substrate for the dopamine transporter (DAT), which explains its selectivity for DAergic neurons. Although the mechanisms of cell death induced by MPP+ have not been fully characterized, it is known that MPP+ is an effective inhibitor of complex I res- piration in isolated mitochondria [13-16]. As a result, a rapid decrease in adenosine triphosphate (ATP) content occurs in the striatum and substantia nigra pars compacta ( $\mathrm{SNpc}$ ), the brain regions most sensitive to MPTP-induced neurotoxicity [17]. Interestingly, a significant ATP depletion can result from as little as $25 \%$ inhibition of complex I [18]. Cell death of DA neurons may occur through both apoptosis and necrosis, depending upon the regimen [19]. Following exposure to MPTP or MPP+, the hydropyridine or its metabolite is cleared from the brain within 12 hours, and the depletion of ATP is no longer evident 24 hours after administration [20-22]. However, the actual neuronal degeneration seems to take a longer period of time [19, 23-25]. These observations raise the possibility that MPTP triggers other events, ultimately responsible for the neurotoxicity.

One mechanism of MPTP-induced neurotoxicity involves oxidative stress [26]. The conversion of MPTP to MPP+ by monoamine oxidase-B (MOA$\mathrm{B})$ in astrocytes is followed by the accumulation of $\mathrm{MPP}+$ in SNpc DAergic neurons via the activity of DAT. Such accumulation in DAergic neurons results in the generation of reactive oxygen species (ROS) by the mitochondria, including nitric oxide (NO), superoxide anion $\left(\mathrm{O}_{2}{ }^{-}\right)$, hydrogen peroxide $\left(\mathrm{H}_{2} \mathrm{O}_{2}\right)$, and hydroxyl radicals $(\bullet \mathrm{OH})[27,28]$. MPP+ also stimulates the release of DA [29]. Excessive auto-oxidation of both intracellular and extracellular DA results in the formation of cytotoxic quinones and highly reactive $\bullet \mathrm{OH}$. Excessive formation of $\bullet \mathrm{OH}$, which has a very short half-life and interacts close to their site of generation in vivo [30], can cause cell damage through chain reactions leading to membrane lipid peroxidation, alterations in membrane fluidity [31,32], protein cross-linking, and DNA damage, which is mediated by base pair mutations [33]. Thus, excessive formation of $\bullet \mathrm{OH}$, which might overwhelm cellular antioxidant defense mechanisms, likely contributes to the death of DAergic neurons [34].

The mitochondrial apoptotic cascade has been suggested to play an important role in MPTP-induced DAergic neurotoxicity $[35,36]$. In support of this idea, MPTP treatment upregulated components of the mitochondrial apoptotic cascade, including cytochrome c and caspase-9 in the substantia nigra (SN) [36]. In addition, the neuronal expression of $\mathrm{p} 35$, a potent and irreversible caspase inhibitor, and overexpression of the anti-apoptotic protein, $\mathrm{Bcl}-2$, conferred a resistance to MPTP-induced neurotoxicity [36, 37]. The mitochondrial apoptotic pathway requires the release of cytochrome $\mathrm{c}$ from mitochondria in connection with 
opening of the mitochondrial transition pore. Importantly, MPP+ induces the opening of the mitochondrial transition pore through the inhibition of complex I and the production of ROS [38]. After cytochrome c is released, it then forms a complex with apoptosis protease activating factor 1 and pro-caspase-9, which results in caspase- 9 activation followed by activation of downstream caspases [39]. The expression of the apoptosis-associated molecule, Nucling, is essential for the release of cytochrome $\mathrm{c}$, the expression of apoptosis protease activating factor 1 , and the induction of caspase-9 following a pro-apoptotic event. Following MPTP treatment in Nucling null mice, the release of cytochrome c was suppressed and DAergic neuron cell death in the SNpc was reduced [40].

There is evidence that supports the idea of excitotoxicity contributing to MPTP-induced DAergic neuron death [41-43]. In this scenario, the depletion of cellular ATP caused by inhibition of complex I of the electron transport chain in mitochondria results in depolarization of the membrane potential of SNpc neurons and an increase in extracellular glutamate levels [41, 44] which, in turn, stimulates N-methyl-Daspartate (NMDA) receptors on the DAergic neurons [45]. A three-fold increase in extracellular glutamate has been measured with microdialysis, in vivo, following chronic MPTP treatment [41]. In addition the toxin treatment leads to an increase in the affinity for glutamate by glutamate transporters in the SNpc [41]. The glutamatergic sources contributing to these enhanced levels are not known, but could include glia in the vicinity, enhanced cortical or subthalamic release from axon terminals on DAergic neurons and/or arise from an exchange with the glutamate/cystine antiporter, which is calcium $\left(\mathrm{Ca}^{2+}\right)$ insensitive but exchanges glutamate from the cytoplasm of the nerve terminal, although the latter remains controversial [41].

The stimulation of NMDA receptors by extracellular glutamate results in an elevation of intracellular $\mathrm{Ca}^{2+}$ via the opening of $\mathrm{Ca}^{2+}$ channels due to an inability of the cell to sequester and pump out $\mathrm{Ca}^{2+}$ [45]. Elevation of intracellular $\mathrm{Ca}^{2+}$ in SNpc neurons activates neuronal nitric oxide synthase (nNOS) and NO is synthesized. NO plays a key role in MPTP-induced neurotoxicity $[46,47]$. $\mathrm{NO}$ reacts with $\mathrm{O}_{2}{ }^{-}$to form peroxynitrite $\left(\mathrm{ONOO}^{-}\right)$. Once formed, $\mathrm{ONOO}^{-}$can diffuse over several cell diameters where it can oxidize lipids, proteins, and damage DNA [48, 49]. DNA damage, in turn, activates the DNA damage-sensing enzyme poly(ADP-ribose) polymerase (PARP) [50, 51]. PARP activation induces PAR polymers and depletes nicotinamide adenine dinucleotide (NAD+) and ATP $[52,53]$. The generation of PAR polymers, the ribosylation of proteins, and the loss of NAD+ and ATP signal to the mitochondria induce apoptosis inducing factor (AIF) release and translocation [54]. AIF, a mitochondrial flavoprotein that mediates caspase-independent cell death [55], translocates from the mitochondria to the nucleus to induce DNA fragmentation and nuclear condensation $[56,57]$. The dismantling of the nuclear structure ultimately leads to cell death.

Inflammation also plays an important role in MPTPinduced neurotoxicity. MPTP treatment causes an inflammatory reaction characterized by infiltration of $\mathrm{T}$ cells into the $\mathrm{SN}$ and striatum, activation of the resident brain macrophages, microglia, and increased gene expression of the proinflammatory cytokines interleukin-1 $\beta$ (IL-1 $\beta$ ), tumor necrosis factor $\alpha$ $(\mathrm{TNF} \alpha)$, and interferon $\gamma$ (INF $\gamma$ ) [58]. Moreover, activated microglia can be phagocytic and release proinflammatory factors such as TNF $\alpha$, prostaglandin E2 (PGE2), INF $\gamma$, and ROS such as $\mathrm{NO}, \mathrm{H}_{2} \mathrm{O}_{2}$, and $\mathrm{O}_{2}{ }^{-}$, which are all toxic to neurons [59]. Injection of the bacterial endotoxin, lipopolysaccharide, into the SNpc induced PD-like changes characterized by activation of microglia and DAergic neuron cell death [60, 61]. Importantly, following MPTP treatment, microglial cell activation occurred prior to DAergic neuron death in the SNpc [62]. An increase in the number and size of microglia and a morphological change consistent with their entering an activated state has been observed in MPTP-treated mice [63]. In addition, microglial cell processes were observed in close association with degenerating profiles [63], supporting a role for microglia in the scavenging of dead and dying neurons [63, 64]. Furuya and colleagues [62] reported that caspase-11, which is predominantly expressed in microglia in the SN, can produce cell death by regulating the expression of cytotoxic cytokines. Caspase-11 null mice were resistant to the neurotoxic effects of an acute MPTP treatment [62]. Interestingly, inhibition of microglia activation relieved the degeneration of DAergic neurons $[65,66]$. Furthermore, NO, a lipophilic radical that is toxic to neurons, is one of the proinflammatory factors released by microglia. Inducible nitric oxide synthase (iNOS) is upregulated in MPTPtreated mice [66], resulting in elevated NO production. The expression of iNOS in activated microglia contributes to the death of DAergic neurons in MPTP toxicity $[67,68]$.

Abnormal protein interactions in the ubiquitinproteasome system (UPS), which degrades short-lived, damaged, and misfolded proteins in an ATP-dependent 

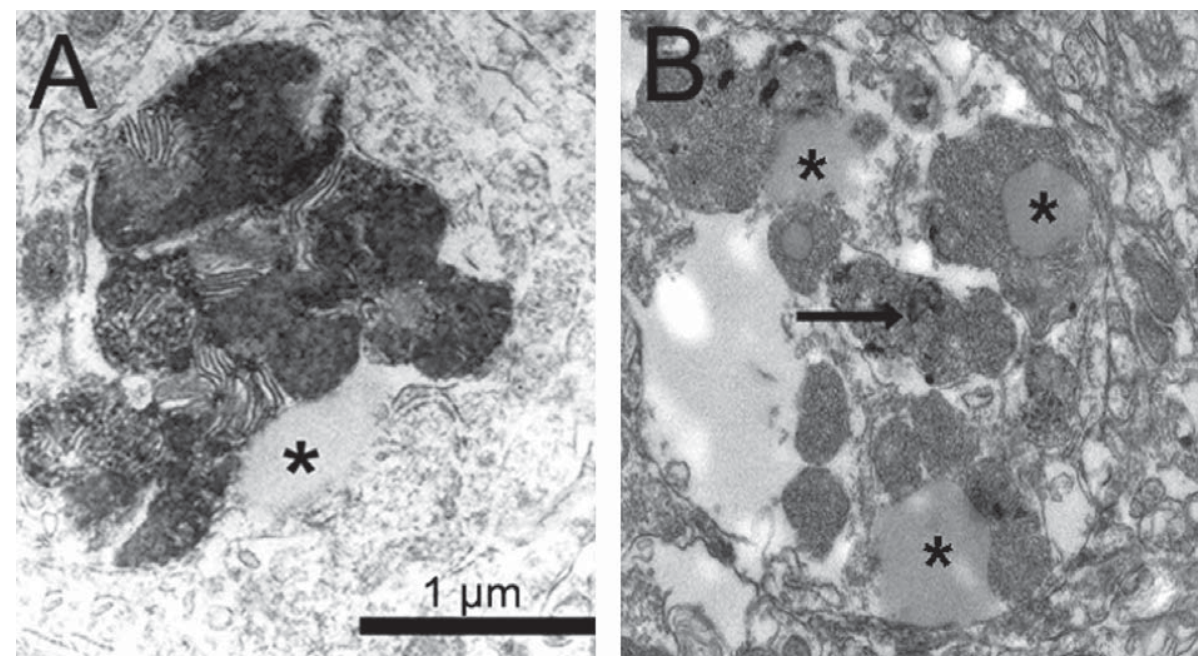

Fig. 2. Electron micrographs illustrating proteinaceous and lipid inclusions in MPTP/P-treated mice. (A) Secondary lysosomes with parallel membranes and lipid droplet (asterisk). (B) Lipid droplets (asterisk) among proteinaceous deposits (arrow).

manner [69] has been proposed as a mechanism of DAergic neuron death in the SNpc [70]. In support of this hypothesis, systemic administration of a proteasome inhibitor led to degeneration of the nigrostriatal pathway [70]. Moreover, chronic and continuous MPTP administration in mice resulted in a long-lasting inhibition of the UPS and degeneration of DAergic neurons in the SN [71]. In contrast, other groups have reported that administration of the proteasome inhibitor did not produce DAergic neurotoxicity and did not enhance MPTP-induced neurotoxicity $[72,73]$. One group reported that proteasome inhibitors protected against MPTP-induced neurotoxicity [74]. Thus, the contribution of a dysregulation of the UPS system in MPTP-induced neurotoxicity remains unclear.

One of the hallmarks of PD, the development of Lewy bodies, has been proposed to be due to a failure of the UPS. It has been proposed that Lewy bodies develop gradually, appearing first as insoluble proteinaceous granules intermingled with filaments that are both ubiquitin and $\alpha$-synuclein positive (see [64] for review). Neither Lewy bodies nor inclusions that resemble these bodies were observed when mice were acutely or subchronically (subacutely) treated with MPTP [75-77]. However, chronic MPTP administration results in the formation of $\alpha$-synuclein positive granular aggregates [75]. Chronic and continuous MPTP administration in mice produced inclusion bodies in remaining neurons in the SN [71]. Additionally, when mice were chronically treated with MPTP and probenecid (MPTP/P), the surviving DA neurons developed accumulations of $\alpha$-synuclein and ubiquitin
[78]. Ultrastructurally, the inclusions, which are more numerous in MPTP/P-treated mice compared to controls, contain granular and filamentous accumulations of protein and lipid droplets (Fig. 2) in association with lipofuscin granules [64]. Taken together, these findings raise the interesting possibility that scientists will be able to devise treatment regimens that fully recapitulate the process of Lewy body formation.

\section{NOT ALL MOUSE STRAINS ARE VULNERABLE TO THE TOXIC EFFECTS OF MPTP}

The neurotoxic effects of MPTP have been demonstrated in humans and other primates, cats, rabbits, and in some rodents [79]. In rodents, only specific mouse strains are sensitive to MPTP [80-86], pointing to genetic influences on the actions of MPTP. Strains of mice differ in their response to MPTP with respect to the degree of striatal DA depletion [9, 83, 86, 87], amount of loss of midbrain DA neurons [88, 89], and behavioral deficits [89]. With regard to degree of SNpc neuron loss, different mouse strains can be characterized as either "sensitive" (i.e., $>50 \% \mathrm{SNpc}$ neuron loss) or "resistant" (i.e., $<25 \%$ SNpc loss) [80, 88].

The basis for differences in sensitivity to MPTP between rodent strains is not well understood. Although several explanations have been offered, no single explanation fully accounts for the phenomenon. The neurotoxicity of MPTP is dependent on the activity of MAO-B, the enzyme that catalyzes the conversion of the MPTP protoxin to the 
dyhdropyrididinium intermediate, 1-methyl-4-phenyl2,3-dihydropyridinium species (MPDP+), which is subsequently oxidized to the toxic MPP+. Thus, it has been proposed that differences in brain MAO-B levels could account for species and strain differences in sensitivity to MPTP. Rats are resistant to MPTP toxicity [84], and differences in MAO activity have been proposed as the reason for their low susceptibility. The mouse strain most sensitive to MPTP, the C57BL/6 strain $[85,90]$, is the only species in which MAO$\mathrm{B}$ activity was greater in the brain than in the liver [91]. Thus, the increased susceptibility of this mouse strain to MPTP may be due, in part, to the limited, systemic detoxification of MPTP by liver MAO-B [91]. However, contrary to this hypothesis, MAO-B overexpressing transgenic mice did not have alterations in their MPTP toxicity profiles compared with controls [92]. In addition, no differences in the vesicular monoamine transporter, which regulates the sequestration of MPP+ inside the cell, were observed in MPTP-sensitive versus resistant strains [93].

Another possible explanation for the strain differences in sensitivity to MPTP is that the different strains have different tolerances to oxidative changes. Although it is known that free radical formation plays an important role in MPTP-induced cell death [94-96], little is known about the different oxidation states of various mouse strains, specifically as it relates to the SNpc. The finding of no difference in free radical production in the striatum of the MPTP-sensitive strain, C57BL/6, and the MPTP-resistant strain, Swiss-Weber [97-99], suggests that free radical production alone is not a sufficient explanation to account for the differences in strain susceptibility.

Several other potential mechanisms for differential sensitivity to MPTP have been explored including differential uptake through the DAT [100], differences in DAT kinetics [101], changes in glutamate transporter function in astrocytes [102], control of $\mathrm{Ca}^{2+}$ influx into SN neurons [103], and functional changes in electron transport chain proteins [104]. Unfortunately, none of these studies are conclusive with regard to their individual role in MPTP-induced neurotoxicity.

Degree of sensitivity across mouse strains has been hypothesized to be related to coat color, with the pigmented strains being more sensitive than the albino strains $[83,87,105,106]$. Although albinism is the result of a lack of melanin pigments, the absence of melanin in mice produced by a point mutation in the gene for tyrosinase, the enzyme that catalyzes the first two steps of melanin synthesis, located on chromosome 7, did not protect the mice from MPTP-induced behavioral deficits, DA depletion in the striatum, and neuron loss in the SNpc [107]. The possibility that the higher sensitivity to MPTP observed in pigmented mice $[105,108]$ is caused by a susceptibility gene located in the same chromosomal region warrants further investigation.

The emerging picture is that susceptibility to MPTP is mostly a polygenetic trait. The MPTP-sensitive strain, C57BL/6, has been crossbred with two MPTP resistant strains, SWR/J and AKR/J. The authors concluded that neuron loss in SNpc following MPTP treatment was autosomal dominant and the polymorphism was carried on the C57BL/6 allele [80]. In contrast, the crossbreeding of an MPTP-sensitive strain (C57BL/6) with a MPTP resistant strain (BALB/c) resulted in a generation of mice that were highly resistant to the toxic effects of MPTP. These results can best be explained by the action of a recessive susceptibility allele in the C57BL/6 genome [85]. Due to the fact that it is highly unlikely that the loci involved in the two studies are the same, the results, taken together, point to the involvement of multiple genes controlling the degree of MPTP toxicity. These findings raise the interesting possibility that sensitivity to MPTP could be controlled by interactions between multiple susceptibility and resistance alleles.

\section{ADVANTAGES AND CAVEATS OF MPTP MOUSE MODELS}

A primary assumption in using the MPTP mouse model is that it faithfully reproduces the naturally occurring neurodegeneration. Certainly, MPP+ is a potent complex I inhibitor in mouse midbrains and the midbrains of PD patients [109]. Moreover, the loss of DA in the striatum depends on the death of DAergic neurons and the degeneration of their axons. Thus, striatal DA loss should reflect the loss of SN DAergic cells as it does in PD patients. In addition, DAergic cell loss in the mouse midbrain follows a similar topographic pattern as seen in human PD. That is, neuronal loss is concentrated in the ventral tier and lateral SNpc neurons as well as in posterior regions, sparing the more anterior and medial cells [110]. But the jury is still out as to whether it faithfully recapitulates PD [111].

The mouse model is useful for studying mitochondrial dysfunction in Parkinsonism [16, 112, 113]. Since PD, like other neurodegenerative diseases, is by nature slow and progressive, the model should mimic the disease course, including the behavioral features of the disease. However, with acute and subchronic 
MPTP treatments, DAergic neurons die quickly and there is little progression in the loss of nigrostriatal DA [114]. The more progressive MPTP treatments include chronic administration of the toxin over weeks (e.g. MPTP plus probenecid [MPTP/P] model)[114], is more progressive, with neurons continuing to die after completion of toxin administration. The pattern of DAergic terminal loss in the striatum, however, does seem to replicate that of PD with most methods of MPTP delivery [110]. In addition, extra-nigral pathology has been demonstrated in reduced levels of monoamines other than DA [115].

The earliest use of the toxin employed a regimen of repeated injections of $20 \mathrm{mg} / \mathrm{kg}$ over 2 days at 2 hour intervals or $10 \mathrm{mg} / \mathrm{kg}$ over 1 day at 1 hour intervals [9]. In general, MPTP rapidly kills DAergic neurons at first (as visualized by tyrosine hydroxylase (TH) immunoreactivity (Table 1)), but can, over time, continue to cause cell death [116]. It is well known that MPTP protocols in mice deliver dramatically different results depending upon the timing used for the regimen. MPTP is generally delivered systemically by repeated i.p. or s.c. injections - i.v. injections are no longer used. If injections are closely spaced (over a single day), the effects on DAergic neurons can be additive (Table 1). This acute regimen leads to a $40-50 \%$ loss of midbrain DAergic neurons [81, 114]. Neurons do not appear to die by apoptosis [19] and inclusions bodies have not been found in the remaining DAergic neurons [117]. However, mouse mortality can be $50 \%$ or more [115]. If the administration is spread out over multiple days (once or twice daily injections over 5-10 days; subchronic or subacute regimen), the toxin appears to be excreted more efficiently (during the first 3-12 hours) and the SN of mice do not lose as many DAergic cells [110] (Table 1). The subchronic regimen induces apoptosis [118]. In addition, no inclusions are formed in the remaining neurons $[117,119]$. Mice survive this subchronic (subacute) delivery very well. When the toxin is delivered chronically with a minipump for 28 days,

Table 1

Mouse model features that recapitulate PD. General definitions of the models appear below*

\begin{tabular}{|c|c|c|c|c|}
\hline Toxin & $\begin{array}{l}\text { Time to } \\
\text { greatest DA } \\
\text { cell loss }\end{array}$ & Striatal DA loss & $\begin{array}{l}\text { DAergic } \\
\text { cell loss in SN }\end{array}$ & Inclusions \\
\hline $\begin{array}{l}\text { Single dose MPTP (30 } \\
\mathrm{mg} / \mathrm{kg} \text { in mice) }\end{array}$ & 12 hours & $\begin{array}{l}>80 \% \text { loss of DA after } 1 \text { day } \\
\text { and }>40 \% \text { loss after } 30 \\
\text { days }\end{array}$ & $20-30 \%$ & Not examined \\
\hline MPTP, acute* (mice) & 12 hours & $\begin{array}{l}>90 \% \text { loss of DA } 7 \text { days after } \\
\text { treatment }\end{array}$ & $40 \%$ & None \\
\hline $\begin{array}{l}\text { MPTP, subchronic } \\
\text { (subacute)* in mice }\end{array}$ & 12 hours & $\begin{array}{l}53 \% \text { loss of DA } 30 \text { days after } \\
\text { treatment }\end{array}$ & $24-40 \%$ & None \\
\hline MPTP/P, chronic* in mice & $\begin{array}{l}3 \text { weeks post- } \\
\text { treatment }\end{array}$ & $\begin{array}{l}\text { 95-98\% loss of DA } 3 \text { weeks } \\
\text { after treatment; } 76 \% \text { loss } \\
\text { after } 6 \text { months }\end{array}$ & $\begin{array}{l}50 \% \text { post-treatment } \\
\text { and } 70 \% 3 \text { weeks } \\
\text { post-treatment }\end{array}$ & $\begin{array}{l}\text { Proteinaceous and } \\
\text { lipid inclusions in } \\
\text { secondary } \\
\text { lysosomes that are } \\
\alpha \text {-synuclein- } \\
\text { positive but do not } \\
\text { resemble Lewy } \\
\text { bodies }\end{array}$ \\
\hline $\begin{array}{l}\text { MPTP, chronic* with } \\
\text { escalating doses in mice }\end{array}$ & $\begin{array}{l}\text { At the end of } \\
\text { treatment ( } 4 \\
\text { weeks) }\end{array}$ & $\begin{array}{l}\text { Dose-dependent loss of DA; } \\
\text { greater than } 70 \% \text { loss of } \\
\text { DA with the two highest } \\
\text { doses only }\end{array}$ & $\begin{array}{l}24 \% \text { loss after } 1 \text { week } \\
\text { and } 62 \% \text { after } 4 \\
\text { weeks following the } \\
\text { highest dose }\end{array}$ & Not examined \\
\hline $\begin{array}{l}\text { MPTP, chronic* with } \\
\text { mini-pumps in mice }\end{array}$ & 21 days & $\begin{array}{l}85 \% \text { loss of DA metabolites } \\
\text { in dorsal striatum }\end{array}$ & $75-80 \%$ & $\begin{array}{l}\alpha \text {-synuclein-positive } \\
\text { inclusions that do } \\
\text { not resemble Lewy } \\
\text { bodies inclusions }\end{array}$ \\
\hline $\begin{array}{l}\mathrm{MPP}+\text {, chronic pump in } \\
\text { rats }\end{array}$ & $\begin{array}{l}42 \text { days or } \\
\text { longer }\end{array}$ & Dose-dependent loss of DA & $40 \%$ & $\begin{array}{l}\text { No inclusions in DA } \\
\text { neurons }\end{array}$ \\
\hline
\end{tabular}

${ }^{*}$ MPTP, acute -4 injections of MPTP in one $24 \mathrm{~h}$ period, 2 hours apart; injections are generally $20-30 \mathrm{mg} / \mathrm{kg}$; ${ }^{*} \mathrm{MPTP}$, subchronic (subacute)

- daily injections over 5 - 10 days. The toxin injected varies from $15 \mathrm{mg} / \mathrm{kg}$ to $30 \mathrm{mg} / \mathrm{kg}$.

*MPTP, chronic -

MPTP/P model, $25 \mathrm{mg} / \mathrm{kg}$ injected every 3.5 days for 5 weeks;

Minipump delivery is continuous, either s.c. or i.p.; 23 or $46 \mathrm{mg} / \mathrm{kg} / \mathrm{day}$ for 14 days or $46 \mathrm{mg} / \mathrm{kg} / \mathrm{day}$ for 28 days;

Escalating dose model included daily injections for 5 days, with the weekend off for 4 weeks. The injected doses were scaled up over time from $4 \mathrm{mg} / \mathrm{kg}$ to $32 \mathrm{mg} / \mathrm{kg}$. 
levels of MPP+ remain measurable in the striatum for at least 21 days. There appears to be no mortality associated with this delivery method, although animals had to be hydrated with $0.9 \%$ saline during the period of minipump delivery of MPTP. The minipump mode of administration kills up to $75 \%$ of SNpc DAergic neurons, reduces striatal metabolites of DA by $85 \%$, and induces the formation of $\alpha$-synuclein-positive inclusions which appeared as 'whorls' in ultrastructural photomicrographs [71] (but see [119], Table 1).

When MPTP is co-administered with probenecid (MPTP/P), which retards the renal and CNS clearance of the toxic metabolites of MPTP, DAergic neurons are lost over a $5-8$ week period $[11,110]$. There is however some mortality associated with this chronic method. Approximately 15 percent of the mice die unless they are kept well hydrated (Meredith, personal observation). Cell death at first involves apoptosis but later, neurons seem to die through other mechanisms $[41,120]$. Within a week after this regimen, approximately $50 \%$ of SN DAergic neurons have been lost and by 3 weeks post-treatment, up to $70 \%$ neurons have died, and a greater than $90 \%$ reduction in striatal DA levels is observed (Table 1). The SN neuron loss (between 65-70\%) and striatal DA loss (76\%) can still be demonstrated 6 months later [110]. In addition, $\alpha-$ synuclein-positive inclusions have been detected in the cytoplasm of the remaining SN DAergic neurons [64, 121] (but see [117]). The nigrostriatal degeneration with MPTP/P therefore appears to be slower than with other models. As noted above, a single dose of MPTP alone causes striatal DA depletion to peak within 12 hours, but with the MPTP/P combination, the striatal DA loss is slowed. Therefore, MPTP/P kills more DA neurons than MPTP alone [110]. This chronic regimen can thus provide a short preclinical 'window' following toxin administration for the introduction of neuroprotective strategies.

Certainly, for the single injection, acute and subchronic protocols, the DAergic neurons disappear rapidly and their loss of $\mathrm{TH}$ immunoreactivity may not reflect actual cell death, since MPTP dramatically blocks $\mathrm{TH}$ gene expression [122]. The THimmunoreactive neurons begin to 'reappear' a few days after toxin administration. Ever since the introduction of unbiased stereology to count $\mathrm{TH}$-immunoreactive neurons stained for Nissl substance at least 7 days following any MPTP treatment, investigators have been able to provide more accurate estimates of DAergic neuronal loss in all MPTP mouse models [114].

A more recent, progressive MPTP model requires repeated injections of escalating doses of MPTP over
4 weeks [123]. The loss of TH-positive neurons is most pronounced following the final, relatively high (32 $\mathrm{mg} / \mathrm{kg}$ ), dose of the toxin. Almost $70 \%$ of the neurons are lost after that stage (Table 1). There are also behavioral changes in the open field that appear to be progressive. The mortality was not reported in this study but could be an important factor. Nevertheless, progression in a model with MPTP is an important advance on the more acute models, and compares favorably with the chronic MPTP model, in which mice continue to lose neurons in the SNpc for 3 weeks after the final injection. Thus, it seems that pre-treating mice with the toxin creates a "stage" whereby DAergic neurons become more sensitive [123].

The apparent lack of Lewy body-like inclusions bodies in the SN is true of all MPTP mouse models $[64,117]$ (Table 1). Minipump delivery reveals 'whorls' in the cytoplasm of remaining DAergic neurons [71]. In the chronic MPTP/P model, SN DAergic neurons have $\alpha$-synuclein-positive inclusions and secondary lysosomes filled with proteinaceous debris and lipid droplets (Fig. 2), the latter of which resemble early deposits in human midbrains of PD patients [64]. When MPTP is delivered i.p. via minipump for 14 days, $\alpha$-synuclein-positive inclusions are also found in the SN DAergic neurons [119]. However, when the toxin is delivered for 28 days either s.c. or i.p. with a minipump, no inclusions are found [119]. Gibrat and colleagues [119] suggest that such differences in inclusion formation are directly related to the sustained action of MPTP on the mitochondria but they cannot explain why longer toxin infusion did not yield inclusions. Thus, the cytoplasm of DAergic neurons of several models show $\alpha$-synuclein- and ubiquitinpositive deposits $[64,71,121]$, which may represent a "pre" Lewy body stage.

An interesting rat model has been introduced using $\mathrm{MPP}+$ infused directly into the brain using an osmotic minipump that delivers the toxin to the left lateral cerebral ventricle [12]. This model is unilateral in order to avoid the moribund condition that arises with extensive bilateral loss of DAergic neurons, as seen with 6-hydroxydopamine lesions. This MPP+ treatment produces a dose-dependent, unilateral loss of striatal DA on the side of the infusion (Table 1). The doses can be varied, but the use of high doses also reduce serotonin levels significantly. One interesting feature of this model is the progressive loss of DA neurons over weeks and the initiation of DA loss in the contralateral striatum. This model may mimic the human condition better than the mouse MPTP models, since unilateral motor deficits are generally 
encountered in the early stages before bilateral deficits show up, similar to idiopathic disease. Lewy body-like inclusions have not been identified, but there are proteinaceous inclusion bodies in the striatum that stain positive for $\alpha$-synuclein. No behavioral assessments were performed so motor deficits cannot be assessed. While the model is technically challenging, it produces a reliable response with low variation, thus making it appealing for testing neuroprotective strategies during the phase of toxic insult and ongoing degeneration, the stage at which PD patients present with the disease.

There remain a few, important, unresolved issues with mouse MPTP models such as the inflammatory response. Neuroinflammation is a hallmark of idiopathic PD [124]. Activated microglia are known to produce pro-inflammatory molecules such as chemokines, cytokines, NO, and ROS [125-127]. The phagocytic activity is beneficial during neuronal development and injury, but dysregulation or excessive activation, can lead to an increased oxidative burden for neurons. Microglial-induced inflammation can be sustained and progressive [128, 129]. Microgliosis persists for years in humans and non-human primates following an acute exposure to MPTP [128, 130] and has been observed in acute and chronic MPTP mouse models [63, 131, 132], but the relationship to DAergic cell death remains undetermined.

Another unresolved issue is the question as to whether older mice, which are more sensitive to MPTP than young adults, would reveal the Parkinsonian pathophysiology better, and the need to validate the relationship between key neurodegenerative features with results from behavioral tests sensitive enough to measure Parkinsonism in rodents [111]. Certainly, the age of the mouse is an important limiting factor in the effectiveness of MPTP. Older mice are approximately 1-2 fold more sensitive to the toxin [133].

\section{BEHAVIORAL DEFICITS IN MPTP MODELS}

Interpreting rodent behavior as Parkinsonian following DAergic lesions is very challenging [134]. Rodent locomotion is controlled centrally in a different manner than that of primates, including humans, and reports on motor deficits in mice administered MPTP differ widely [111]. The most common behavioral test is the open field, where changes in the time spent moving, rearing, or the distance traveled are measured by breaks in infrared beams that cross the box. Using the open field box, mice show a paucity of move- ment shortly after toxin administration ceases [84], but these deficits may disappear over time, perhaps due to the diminishing effects of the toxin on peripheral organs [112]. There are, however, a few reports that show that MPTP-treated mice have reduced locomotion and rearing many weeks later [71, 135, 136], but there are also reports of no change in locomotion and even hyperactivity in mice [132, 137-139].

Another popular way of measuring behavior in MPTP-treated mice is with the Rotarod. This automated device provides an end-point measurement that marks the duration the mouse ran or walked on the rod. In order to use the equipment successfully, mice must be trained to stay on the rod at speeds that exceed their normal pace $[140,141]$. Once animals are trained, they can be tested following DAergic lesions. While DA depletion can be detected, especially with unilateral lesions [141], the extent of depletion cannot be correlated with the end-point measure, and bilateral MPTP lesions are even more difficult to detect [111] (but see [132]). Moreover, the rod does not detect changes in balance or coordination unless stepping is videotaped [142].

Mice, like other rodents, utilize their forepaws for most "activities of daily living", and the basal ganglia circuitry define many aspects of forepaw movement but have little impact on hindlimb activity [111]. Thus, tests of forepaw usage will more likely exemplify basal ganglia deficits compared to general tests of movement [111]. Studies have shown that the pole or grid test, both of which focus on forepaw manipulation, can detect even subtle deficits in the DAergic system $[84,111,143,144]$. Other forepaw tests such as the adhesive removal test, the elevated beam traversal test (missteps in forepaws or hindpaws) and the stepping test (forepaw test) are all sensitive to a lesion of the nigrostriatal pathway $[145,146]$. However, none of the motor deficits are easily correlated with loss of SN neurons, striatal DA levels, or the dose of MPTP [111]. More sophisticated tests are needed to detect the subtleties of motor dysfunction in quadripedal rodents.

\section{TESTING THERAPEUTIC TREATMENTS WITH THE MOUSE MPTP MODELS}

Traditionally, therapies for symptomatic relief of PD disabling deficits were tested using the 6hydroxydopamine rat model. However, once the MPTP mouse models were developed, they became increasingly used for testing neuroprotective treatments 
(Fig. 1). MPTP-treated mice receive a therapeutic treatment either shortly before or after toxin administration. Measures of treatment success often include 1) behavioral tests of the model in the open field, on the rotarod and/or on the grid or traversal beam to measure footfaults; 2) "rescue" of TH-immunoreactive neurons in the SN, and 3) enhanced DA levels in the striatum. MPTP mouse models have been used to test the efficacy of many different types of drugs, including drugs that potentially neuroprotect the DAergic neurons in the midbrain. This review cannot begin to cover the extensive literature in which MPTP mouse models have been employed to test therapeutic approaches to abrogating the pathophysiology of Parkinsonism. The paragraphs below provide selected examples of therapies tested with MPTP-treated mice.

The potential causes of cell death in PD are not known. Among them, oxidative stress, inflammation and excitotoxicity have been suggested as important perpetrators. Free radical generation is increased in PD and mouse MPTP models. A number of drugs are known to scavenge free radicals and are, therefore, thought to protect DA neurons. Several of these drugs have been tested using MPTP models. For example, free radical scavengers have the ability to inhibit peroxide formation following oxidative metabolism of DA [147]. Various MAO-B inhibitors have been tested in mice and found to rescue DAergic neurons following MPTP [76, 148]. Of course, MPTP is converted to MPP+ via MAO-B; thus inhibitors of this enzyme are particularly effective in preventing MPTP toxicity and may not be as relevant for treating idiopathic PD. Nevertheless, MAO-B inhibitors play other roles in regulating free radicals. For example, Selegeline, a MAO-B inhibitor, increases the activity of antioxidant enzymes, such as superoxide dismutase, when administered before MPTP treatment [149]. There are also reports that DA D2 receptor agonists, such as bromocriptine, pergolide, cabergoline, and ropinirole scavenge hydroxyl or nitric oxide radicals [150]. A number of different free radical scavengers have been tested in MPTP models and in PD patients with mixed success.

Many investigators have implicated inflammation in the death of DAergic neurons. As noted above, microglial activation of the SN has been demonstrated in human patients exposed to MPTP and in mouse MPTP models [128, 130]. Activated microglia are thought to contribute to the DAergic neuron demise by releasing toxic compounds including ROS, reactive nitrogen species, and pro-inflammatory cytokines [151-153]. Several studies have used the
MPTP mouse model to explore the protective activity of a family of transcription factors, peroxisome proliferator-activated receptors (PPARs), which have anti-inflammatory effects. The activation of PPARs can protect the DAergic neurons when administered prior to MPTP treatment [154]. Another compound, minocycline, exerts anti-inflammatory effects, which are distinct from its antimicrobial actions [155]. Several labs have studied the anti-inflammatory effects in a mouse MPTP model. Du and colleagues [156] showed that minocycline reduced glial-activated iNOS expression and prevented the death of DAergic neurons when administered in advance of MPTP treatment. They also showed that minocycline protects against MPTP toxicity when administered by 4 hours after MPTP treatment [156]. However, the studies of Yang and colleagues [157] using minocycline in the MPTP-treated mouse pointed to an increase in DAergic cell death, even though the drug was able to inhibit microglial activation. These studies differed in the time of administration and the MPTP protocol, which could account for the different results.

Glutamate excitotoxicity has often been raised as the mechanism of cell death in PD and the NMDA receptor has been considered as the trigger for this toxicity. MPTP exposure in mice triggers numerous cytotoxic changes, especially in the mitochondria, which may ultimately lead to DA depletion and cell death, which can occur within a few hours. The DAergic neurons have reduced levels of bioenergy due to compromise of mitochondrial respiration, raising the question whether neurons are able to cope with even low levels of glutamate stimulation and subsequent $\mathrm{Ca}^{2+}$ influx. Numerous studies have examined whether NMDA antagonists in MPTP-treated mice could protect the DAergic neurons against glutamate toxicity but results have generally been disappointing [158-162]. Blocking the NMDA receptor has not been able to prevent degeneration in MPTP models, but antagonists have transiently protected the striatum from DA depletion [158]. Nevertheless, extracellular glutamate levels are significantly elevated following chronic MPTP treatment [42], suggesting further that glutamate may be important in neurodegeneration in PD. It is well known that adult SN DAergic neurons are $\mathrm{Ca}^{2+}$-dependent pacemakers, a process that is driven primarily by L-type $\mathrm{Ca}^{2+}$ channels [163-165]. Thus, already compromised neurons may be subject to sustained high levels of cytosolic $\mathrm{Ca}^{2+}$ through glutamate stimulation. Calcium further enhances free radical production and could be important in DAergic death. In MPTP models, these L-type $\mathrm{Ca}^{2+}$ channels have been blocked 
to decrease the amount of stress on the neurons and, therefore, provide neuroprotection [103, 144]. Such an approach appears to protect the DAergic neurons better than a blockade of the NMDA receptors, suggesting that $\mathrm{Ca}^{2+}$ influx through ion channels is a key factor in triggering DAergic cell death.

\section{CONCLUSIONS}

The mouse MPTP model has been an important tool for understanding PD, despite the fact that this model does not fully recapitulate the broad spectrum of PD symptoms. Chronic or continuous treatment with MPTP produces a barrage of insults to SNpc DAergic neurons including ATP deprivation, oxidative stress, activation of the mitochondrial apoptotic cascade, excitotoxicity, inflammation, dysregulation of the UPS, and the formation of inclusion bodies. The effects of this barrage of insults, acting in isolation and in combination, ultimately leads to the demise of $\mathrm{SNpc}$ DAergic neurons, sometimes in a progressive manner. Research on strain differences has revealed that sensitivity to MPTP is likely controlled by an interaction between multiple susceptibility and resistance alleles [80, 85]. This is an important line of research since the identification of the genes that confer susceptibility and resistance to MPTP will lead to new therapeutic targets. No model is perfect, however. The fact that rodents have a behavioral repertoire that preclude replication of many typical PD motor deficits is a disadvantage for these rodent models [111]. Nevertheless, the use of the MPTP mouse model has resulted in a better understanding of the causes of cell death, the role of mitochondria in the disease, and the exploration of neuroprotection and neurorestorative strategies. Moreover, there have been important advances in the development of MPTP models that more faithfully reproduce a PD-like disease progression. For example, chronic MPTP models provide a short preclinical 'window' following toxin administration for the introduction of neuroprotective strategies $[41,63,78,110,121]$ and i.c.v. strategies produce a progressive neuron loss [12].

\section{ACKNOWLEDGMENTS}

This work was supported in part by grants NS41799 (GEM) and W81XWH-05-1-0580 (USAMRMC NETRP Program to GEM). The authors thank M. Adam Palmer for his editorial assistance.

\section{REFERENCES}

[1] Di Monte D, Sandy MS, Ekström G, \& Smith MT (1986) Comparative studies on the mechanisms of paraquat and 1-methyl-4-phenylpyridine (MPP+) cytotoxicity. Biochem Biophys Res Comm, 137, 303-309.

[2] McNaught KS, Thull U, Carrupt PA, Altomare C, Cellamare S, Carotti A, Testa B, Jenner P, \& Marsden CD (1996) Effects of isoquinoline derivatives structurally related to 1-methyl-4-phenyl-1,2,3,6-tetrahydropyridine (MPTP) on mitochondrial respiration. Biochem Pharmacol, 51, 15031511.

[3] Betarbet R, Sherer TB, MacKenzie G, Garcia-Osuna M, Panov AV, \& Greenamyre JT (2000) Chronic systemic pesticide exposure reproduces features of Parkinson's disease. Nat Neurosci, 3, 1301-1306.

[4] Brooks AI, Chadwick CA, Gelbard HA, Cory-Slechta DA, \& Federoff HJ (1999) Paraquat elicited neurobehavioral syndrome caused by dopaminergic neuron loss. Brain Res, $\mathbf{8 2 3}$, 1-10.

[5] Chun HS, Gibson GE, DeGiorgio LA, Zhang H, Kidd VJ, \& Son JH (2001) Dopaminergic cell death induced by $\operatorname{MPP}(+)$, oxidant and specific neurotoxicants shares the common molecular mechanism. J Neurochem, 76, 10101021 .

[6] Thiruchelvam M, Richfield EK, Baggs RB, Tank AW, \& Cory-Slechta DA (2000) The nigrostriatal dopamine system as a preferential target of repeated exposures to combined paraquat and maneb: implications for Parkinson's disease. J Neurosci, 20, 9207-9214.

[7] Davis GC, Williams AC, Markey SP, Ebert MH, Caine ED, Reichert CM, \& Kopin IJ (1979) Chronic parkinsonism secondary to intravenous injection of meperidine analogues. Psychiatry Res, 1, 249-254.

[8] Langston JW, Forno LS, Rebert CS, \& Irwin I (1984) Selective nigral toxicity after systemic administration of 1methyl-4-phenyl-1,2,3,6-tetrahydropyridine (MPTP) in the squirrel monkey. Brain Res, 292, 390-394.

[9] Sonsalla PK \& Heikkila RE (1986) The influence of dose and dosing interval on MPTP-induced dopaminergic neurotoxicity in mice. Eur J Pharmacol, 129, 339-345.

[10] Marini AM, Lipsky RH, Schwartz JP, \& Kopin IJ (1992) Accumulation of 1-methyl-4-phenyl-1,2,3,6-tetrahydropyridine in cultured cerebellar astrocytes. $J$ Neurochem, $\mathbf{5 8}$, 1250-1258.

[11] Lau Y-S, Fung YK, Trobough KL, Cashman JR, \& Wilson JA (1991) Depletion of striatal dopamine by the $N$-oxide of 1-methyl-4-phenyl-1,2,3,6-tetrahydropyridine (MPTP)treated mice. Neurotoxicology, 12, 189-199.

[12] Yazdani U, German DC, Liang CL, Manzino L, Sonsalla PK, \& Zeevalk GD (2006) Rat model of Parkinson's disease: Chronic central delivery of 1-methyl-4-phenylpyridinium (MPP+). Exp Neurol, 200, 172-183.

[13] Nicklas WJ, Vyas I, \& Heikkila RE (1985) Inhibition of NADH-linked oxidation in brain mitochondria by 1methyl-4-phenyl-pyridine, a metabolite of the neurotoxin, 1-methyl-4-phenyl-1,2,5,6-tetrahydropyridine. Life Sci, 36, 2503-2508.

[14] Ramsay RR, Dadgar J, Trevor A, \& Singer TP (1986) Energy-driven uptake of N-methyl-4-phenylpyridine by brain mitochondria mediates the toxicity of MPTP. Life Sci, 39, 581-588.

[15] Sayre LM, Wang F, \& Hoppel CL (1989) Tetraphenylborate potentiates the respiratory inhibition by the dopaminergic neurotoxin MPP+ in both electron transport particles 
and intact mitochondria. Biochem Biophys Res Comm, 161, 809-818.

[16] Przedborski S \& Jackson-Lewis V (1998) Mechanisms of MPTP toxicity. Mov Disord, 13, 35-38.

[17] Chan P, DeLanney LE, Irwin I, Langston JW, \& Di Mont D (1991) Rapid ATP loss caused by 1-methyl-4-phenyl1,2,3,6-tetrahydropyridine in mouse brain. J Neurochem, $\mathbf{5 7}$, 348-351.

[18] Davey GP, Peuchen S, \& Clark JB (1998) Energy thresholds in brain mitochondria. Potential involvement in neurodegeneration. J Biol Chem, 273, 12753-12757.

[19] Jackson-Lewis V, Jakowec M, Burke RE, \& Przedborski S (1995) Time course and morphology of dopaminergic neuronal cell death caused by the neurotoxin 1-methyl4-phenyl-1,2,3,6-tetrahydropyridine. Neurodegeneration, $\mathbf{4}$, 257-269.

[20] Irwin I, DeLanney LE, \& Langston JW (1993) MPTP and aging. Studies in the C57BL/6 mouse. Adv Neurol, 60, 197 206.

[21] Chan P, DeLanney LE, Irwin I, Langston JW, \& Di Monte D (1991) Rapid ATP loss caused by 1-methyl-4-phenyl1,2,3,6-tetrahydropyridine in mouse brain. J Neurochem, $\mathbf{5 7}$, 348-351.

[22] Chan P, Langston JW, Irwin I, DeLanney LE, \& Di Monte DA (1993) 2-Deoxyglucose enhances 1-methyl-4-phenyl1,2,3,6-tetrahydropyridine-induced ATP loss in the mouse brain. $J$ Neurochem, 61, 610-616.

[23] Ricaurte GA, Langston JW, Delanney LE, Irwin I, Peroutka SJ, \& Forno LS (1986) Fate of nigrostriatal neurons in young mature mice given 1-methyl-4-phenyl-1,2,3,6tetrahydropyridine: a neurochemical and morphological reassessment. Brain Res, 376, 117-124.

[24] Janson AM, Fuxe K, Sunderström E, Agnati LF, \& Goldstein M (1988) Chronic nicotine treatment partly protects against the 1-methyl-4-phenyl-1,2,3,6-tetrahydropyridine-induced degeneration of nigrostriatal dopamine neurons in the black mouse. Acta Physiol Scand, 132, 589591.

[25] Chadi G, Moller A, Rosen L, Janson AM, Agnati LA, Goldstein M, Ogren S-O, Pettersson RF, \& Fuxe K (1993) Protective actions of human recombinant basic fibroblast growth factor on MPTP-lesioned nigrostriatal dopamine neurons after intraventricular infusion. Exp Brain Res, 97, 145-158.

[26] Gerlach M \& Riederer P (1996) Animal models of Parkinson's disease: an empirical comparison with the phenomenology of the disease in man. J Neural Transm, 103, 987-1041.

[27] Zang LY \& Misra HP (1993) Generation of reactive oxygen species during the monoamine oxidase-catalyzed oxidation of the neurotoxicant, 1-methyl-4-phenyl-1,2,3,6tetrahydropyridine. J Biol Chem, 268, 16504-16512.

[28] Muralikrishnan D \& Mohanakumar KP (1998) Neuroprotection by bromocriptine against 1-methyl-4-phenyl1,2,3,6-tetrahydropyridine-induced neurotoxicity in mice. FASEB J, 12, 905-912.

[29] Obata T \& Chiueh CC (1992) In vivo trapping of hydroxyl free radicals in the striatum using intracranial microdialysis perfusion of salicylate: effects of MPTP, MPDP+, and MPP+. J Neural Transm Gen Sect, 89, 139-145.

[30] Halliwell B (1989) Oxidants and the central nervous system: some fundamental questions. Is oxidant damage relevant to Parkinson's disease, Alzheimer's disease, traumatic injury or stroke? Acta Neurol Scand Suppl, 126, 23-33.
[31] Halliwell B (1992) Reactive oxygen species and the central nervous system. J Neurochem, 59, 1609-1623.

[32] Götz ME, Künig G, Riederer P \& Youdim MB (1994) Oxidative stress: free radical production in neural degeneration. Pharmacol Ther, 63, 37-122.

[33] Dedon PC, Plastaras JP, Rouzer CA, \& Marnett LJ (1998) Indirect mutagenesis by oxidative DNA damage: formation of the pyrimidopurinone adduct of deoxyguanosine by base propenal. Proc Natl Acad Sci USA, 95, 11113-11116.

[34] Obata T, Yamanaka Y, Kinemuchi H, \& Oreland L (2001) Release of dopamine by perfusion with 1-methyl4-phenylpyridinium ion $(\mathrm{MPP}(+))$ into the striatum is associated with hydroxyl free radical generation. Brain Res, 906, 170-175.

[35] Mochizuki H, Hayakawa H, Migita M, Shibata M, Tanaka R, Suzuki A, Shimo-Nakanishi Y, Urabe T, Yamada M, Tamayose K, Shimada T, Miura M, \& Mizuno Y (2001) An AAV-derived Apaf-1 dominant negative inhibitor prevents MPTP toxicity as antiapoptotic gene therapy for Parkinson's disease. Proc Natl Acad Sci USA, 98, 10918-10923.

[36] Viswanath V, Wu Y, Boonplueang R, Chen S, Stevensson FF, Yantiri F, Beal MF, \& Andersen JK (2001) Caspase-9 activation results in downstream caspase-8 activation and Bid cleavage in 1-methyl-4-phenyl-1,2,3,6-tetrahydropyridineinduced Parkinson's disease. J Neurosci, 21, 9519-9528.

[37] Yang L, Matthews RT, Schulz JB, Klockgether T, Liao AW, Martinou JC, Penney JB Jr, Hyman BT, \& Beal MF (1998) 1-methyl-4-phenyl-1,2,3,6-tetrahydropyridine neurotoxicity is attenuated in mice overexpressing $\mathrm{Bcl}-2 . J$ Neurosci, 18, 8145-8152.

[38] Cassarino DS, Parks JK, Parker WD Jr, \& Bennett JP $\mathrm{Jr}$ (1999) The parkinsonian neurotoxin MPP+ opens the mitochondrial permeability transition pore and releases cytochrome $\mathrm{c}$ in isolated mitochondria via an oxidative mechanism. Biochim Biophys Acta, 1453, 49-62.

[39] Srinivasula SM, Ahmad M, Fernandes-Alnemri T, \& Alnemri ES (1998) Autoactivation of procaspase-9 by Apaf1-mediated oligomerization. Mol Cell, 1, 949-957.

[40] Teng X, Sakai T, Liu L, Sakai R, Kaji R, \& Fukui K (2006) Attenuation of MPTP-induced neurotoxicity and locomotor dysfunction in nucling-deficient mice via suppression of the apoptosome pathway. J Neurochem, 97, 1126-1135.

[41] Meredith GE, Totterdell S, Beales M, \& Meshul CK (2009) Impaired glutamate homeostasis and programmed cell death in a chronic MPTP mouse model of Parkinson's disease. Exp Neurol, 219, 334-340.

[42] Sonsalla PK, Albers DS, \& Zeevalk GD (1998) Role of glutamate in neurodegeneration of dopamine neurons in several animal models of parkinsonism. Amino Acids, 14, 69-74.

[43] Turski L, Bressler K, Rettig KJ, Löschmann PA, \& Wachtel H (1991) Protection of substantia nigra from MPP+ neurotoxicity by N-methyl-D-aspartate antagonists. Nature, $\mathbf{3 4 9}$, 414-418.

[44] Novelli A, Reilly JA, Lysko PG, \& Henneberry RC (1988) Glutamate becomes neurotoxic via the N-methylD-aspartate receptor when intracellular energy levels are reduced. Brain Res, 451, 205-212.

[45] Perier C, Tieu K, Guégan C, Caspersen C, Jackson-Lewis V, Carelli V, Martinuzzi A, Hirano M, Przedborski S, \& Villa M (2005) Complex I deficiency primes Bax-dependent neuronal apoptosis through mitochondrial oxidative damage. Proc Natl Acad Sci USA, 102, 19126-19131.

[46] Hantraye P, Brouillet E, Ferrante R, Palfi S, Dolan R, Matthews RT, \& Beal MF (1996) Inhibition of neuronal 
nitric oxide synthase prevents MPTP-induced parkinsonism in baboons. Nat Med, 2, 1017-1021.

[47] Przedborski S, Jackson-Lewis V, Yokoyama R, Shibata T, Dawson VL, \& Dawson TM (1996) Role of neuronal nitric oxide in 1-methyl-4-phenyl-1,2,3,6-tetrahydropyridine (MPTP)-induced dopaminergic neurotoxicity. Proc Natl Acad Sci USA, 93, 4565-4571.

[48] Beckman JS \& Crow JP (1993) Pathological implications of nitric oxide, superoxide and peroxynitrite formation. Biochem Soc Trans, 21, 330-334.

[49] Dawson VL \& Dawson TM (1996) Nitric oxide neurotoxicity. J Chem Neuroanat, 10, 179-190.

[50] Mandir AS, Przedborski S, Jackson-Lewis V, Wang ZQ, Simbulan-Rosenthal CM, Smulson ME, Hoffman BE, Guastella DB, Dawson VL, \& Dawson TM (1999) Poly(ADP-ribose) polymerase activation mediates 1-methyl-4-phenyl-1,2,3,6-tetrahydropyridine (MPTP)induced parkinsonism. Proc Natl Acad Sci USA, 96, 5774-5779.

[51] Zhang J, Dawson VL, Dawson TM, \& Snyder SH (1994) Nitric oxide activation of poly(ADP-ribose) synthetase in neurotoxicity. Science, 263, 687-689.

[52] Cosi C \& Marien M (1998) Decrease in mouse brain NAD+ and ATP induced by 1-methyl-4-phenyl1,2,3,6-tetrahydropyridine (MPTP): prevention by the poly(ADP-ribose) polymerase inhibitor, benzamide. Brain Res, 809, 58-67.

[53] Cosi C \& Marien M (1999) Implication of poly (ADPribose) polymerase (PARP) in neurodegeneration and brain energy metabolism. Decreases in mouse brain NAD+ and ATP caused by MPTP are prevented by the PARP inhibitor benzamide. Ann NY Acad Sci, 890, 227-239.

[54] Yu SW, Wang H, Poitras MF, Coombs C, Bowers WJ, Federoff HJ, Poirier GG, Dawson TM, \& Dawson VL (2002) Mediation of poly(ADP-ribose) polymerase-1-dependent cell death by apoptosis-inducing factor. Science, 297, 259263.

[55] Susin SA, Lorenzo HK, Zamzami N, Marzo I, Snow BE, Brothers GM, Mangion J, Jacotot E, Costantini P, Loeffler M, Larochette N, Goodlett DR, Aebersold R, Siderovski DP, Penninger JM, \& Kroemer G (1999) Molecular characterization of mitochondrial apoptosis-inducing factor. Nature, 397, 441-446.

[56] Daugas E, Susin SA, Zamzami N, Ferri KF, Irinopoulou T, Larochette N, Prévost MC, Leber B, Andrews D, Penninger J, \& Kroemer G (2000) Mitochondrio-nuclear translocation of AIF in apoptosis and necrosis. FASEB J, 14, 729739.

[57] Joza N, Susin SA, Daugas E, Stanford WL, Cho SK, Li CY, Sasaki T, Elia AJ, Cheng HY, Ravagnan L, Ferri KF, Zamzani N, Wakeham A, Hakem R, Yoshida H, Kong YY, Mak TW, Zúñiga-Pflücker JC, Kroemer G, \& Penninger JM (2001) Essential role of the mitochondrial apoptosisinducing factor in programmed cell death. Nature, 410, 549554.

[58] Kurkowska-Jastrzebska I, Balkowiec-Iskra E, Ciesielska A, Joniec I, Cudna A, Zaremba MM, Czlonkowski A, \& Czlonkowska A (2009) Decreased inflammation and augmented expression of trophic factors correlate with MOG-induced neuroprotection of the injured nigrostriatal system in the murine MPTP model of Parkinson's disease. Int Immunopharmacol, 9, 781-791.

[59] Banati RB, Gehrmann J, Schubert P, \& Kreutzberg GW (1993) Cytotoxicity of microglia. Glia, 7, 111-118.

[60] Costaño A, Herrera AJ, Cano J, \& Machado A (1998) Lipopolysaccharide intranigral injection induces inflamma- tory reaction and damage in nigrostriatal dopaminergic system. $J$ Neurochem, 70, 1584-1592.

[61] Gao HM, Jiang J, Wilson B, Zhang W, Hong JS, \& Liu B (2002) Microglial activation-mediated delayed and progressive degeneration of rat nigral dopaminergic neurons: relevance to Parkinson's disease. J Neurochem 81, 1285 1297.

[62] Furuya T, Hayakawa H, Yamada M, Yoshima K, Hisahara S, Miura M, Mizuno Y, \& Mochizuki H (2004) Caspase-11 mediates inflammatory dopaminergic cell death in the 1methyl-4-phenyl-1,2,3,6-tetrahydropyridine mouse model of Parkinson's disease. J Neurosci, 24, 1865-1872.

[63] Meredith GE, Dervan A, \& Totterdell S (2005) Activated microglia persist in the substantia nigra of a chronic MPTP mouse model of Parkinson's disease. Adv Beh Biol, 56, 341347.

[64] Meredith GE, Halliday GM, \& Totterdell S (2004) A critical review of the development and importance of proteinaceous aggregates in animal models of Parkinson's disease: new insights into lewy body formation. Parkinsonism Rel Disord, 10, 191-202.

[65] Kawasaki T, Ago Y, Kitao T, Nashida T, Takagi A, Takuma K, \& Matsuda T (2008) A neuroprotective agent, T-817MA (1-3-[2-(1-benzothiophen-5yl)ethoxy]propyl azetidin-3-ol maleate), prevents 1-methyl4-phenyl-1,2,3,6-tetrahydropyridine-induced toxicity in mice. Neuropharmacology, 55, 654-660.

[66] Wu DC, Jackson-Lewis V, Vila M, Tieu K, Teismann P, Vadseth C, Choi DK, Ischiropoulos H, \& Przedborski S (2002) Blockade of microglial activation is neuroprotective in the 1-methyl-4-phenyl-1,2,3,6-tetrahydropyridine mouse model of Parkinson disease. J Neurosci, 22, 17631771.

[67] Dehmer T, Lindenau J, Haid S, Dichgans J, \& Schulz JB (2000) Deficiency of inducible nitric oxide synthase protects against MPTP toxicity in vivo. J Neurochem, 74, 2213-2216.

[68] Liberatore GT, Jackson-Lewis V, Vukosavic S, Mandir AS, Vila M, McAuliffe WG, Dawson VL, Dawson TM, \& Przedborski S (1999) Inducible nitric oxide synthase stimulates dopaminergic neurodegeneration in the MPTP model of Parkinson disease. Nat Med, 5, 1403-1409.

[69] Sherman MY \& Goldberg AL (2001) Cellular defenses against unfolded proteins: a cell biologist thinks about neurodegenerative diseases. Neuron, 29, 15-32.

[70] McNaught KS, Perl DP, Brownell AL, \& Olanow CW (2004) Systemic exposure to proteasome inhibitors causes a progressive model of Parkinson's disease. Ann Neurol, 56, 149-162.

[71] Fornai F, Schlüter OM, Lenzi P, Gesi M, Ruffoli R, Ferrucci M, Lazzeri G, Busceti CL, Pontarelli F, Battaglia G, Pellegrini A, Nicoletti F, Ruggieri S, Paparelli A, \& Südhof TC (2005) Parkinson-like syndrome induced by continuous MPTP infusion: convergent roles of the ubiquitin-proteasome system and alpha-synuclein. Proc Natl Acad Sci USA, 102, 3413-3418.

[72] Kodoguchi N, Kimoto H, Yano R, Kato H, \& Araki T (2008) Failure of acute administration with proteasome inhibitor to provide a model of Parkinson's disease in mice. Metab Brain Dis, 23, 147-154.

[73] Kodoguchi N, Umeda M, Kato H, \& Araki T (2008) Proteasome inhibitor does not enhance MPTP neurotoxicity in mice. Cell Mol Neurobiol, 28, 971-979.

[74] Oshikawa T, Kuroiwa H, Yano R, Yokoyama H, Kadoguchi N, Kato H, \& Araki T (2009) Systemic administration of proteasome inhibitor protects against MPTP neurotoxicity in mice. Cell Mol Neurobiol, 29, 769-777. 
[75] Forno LS, DeLanney LE, Irwin I, \& Langston JW (1993) Similarities and differences between MPTP-induced parkinsonism and Parkinson's disease. Neuropathologic considerations. Adv Neurol, 60, 600-608.

[76] Heikkila RE, Hess A, \& Duvoisin RC (1984) Dopaminergic toxicity of 1-methyl-4-phenyl-1,2,3,6-tetrahydropyridine in mice. Science, 224, 1451-1453.

[77] Vila M, Vukosavic S, Jackson-Lewis V, Neystat M, Jakowec M, \& Przedborski S (2000) Alpha-synuclein up-regulation in substantia nigra dopaminergic neurons following administration of the parkinsonian toxin MPTP. J Neurochem, 74, 721-729.

[78] Meredith GE, Totterdell S, Petroske E, Santa Cruz K, Callison RC, \& Lau YS JJr (2002) Lysosomal malfunction accompanies alpha-synuclein aggregation in a progressive mouse model of Parkinson's disease. Brain Res, 956, 156165.

[79] Donnan GA, Kaczmarczyk SJ, Solopotias T, Rowe P, Kalnins RM, Vajda FJ, \& Mendelsohn FA (1986) The neurochemical and clinical effects of 1-methyl-4-phenyl1,2,3,6-tetrahydropyridine in small animals. Clin Exp Neurol, 22, 155-164.

[80] Hamre K, Tharp R, Poon K, Xiong X, \& Smeyne RJ (1999) Differential strain susceptibility following 1-methyl-4phenyl-1,2,3,6-tetrahydropyridine (MPTP) administration acts in an autosomal dominant fashion: quantitative analysis in seven strains of Mus Musculus. Brain Res, 828, 91 103.

[81] Jackson-Lewis V \& Przedborski S (2007) Protocol for the MPTP mouse model of Parkinson's disease. Nature Protocols, 2, 141-151.

[82] Mitra N, Mohanakumar KP, \& Ganguly DK (1994) Resistance of golden hamster to 1-methyl-4-phenyl-1,2,3,6tetrahydropyridine: relationship with low levels of regional monoamine oxidase B. B J Neurochem, 62, 1906-1912.

[83] Riachi NJ \& Harik SI (1988) Strain differences in systemic 1-methyl-4-phenyl-1,2,3,6-tetrahydropyridine neurotoxicity in mice correlate best with monoamine oxidase activity at the blood-brain barrier. Life Sci 42, 2359-2363.

[84] Sedelis M, Hofele K, Auburger GW, Morgan S, Huston JP, \& Schwarting RK (2000) MPTP susceptibility in the mouse: behavioral, neurochemical, and histological analysis of gender and strain differences. Behavior Genetics, 30, 171182.

[85] Sedelis M, Hofele K, Auburger GW, Morgan S, Huston JP, \& Schwarting RK (2000) Evidence for resistance to MPTP in C57BL/6 X BALB/c F1 hybrids as compared with their progenitor strains. Neuroreport, 11, 1093-1096.

[86] Sunderström E, Strömberg I, Tsutsumi T, Olson L, \& Johsson G (1987) Studies on the effect of 1-methyl4-phenyl-1,2,3,6-tetrahydropyridine (MPTP) on central catecholamine neurons in C57BL/6 mice. Comparison with three other strains of mice. Brain Res, 405, 26-38.

[87] Muthane U, Ramsay KA, Jiang H, Jackson-Lewis V, Donaldson D, Fernando S, Ferreira M, \& Przedborski S. (1994) Differences in nigral neuron number and sensitivity to 1methyl-4-phenyl-1,2,3,6-tetrahydropyridine in C57/BL and CD-1 mice. Exper Neurol, 126, 195-204.

[88] German DC, Nelson EL, Liang CL, Speciale SG, Sinton CM, \& Sonsalla PK (1996) The neurotoxin MPTP causes degeneration of specific nucleus A8, A9 and A10 dopaminergic neurons in the mouse. Neurodegeneration, 5, 299-312.

[89] Sedelis M, Hofele K, Schwarting RK, Huston JP, \& Belknap JK (2003) Chromosomal loci influencing the susceptibility to the parkinsonian neurotoxin 1-methyl-4-phenyl-1,2,3,6tetrahydropyridine. J Neurosci, 23, 8247-8253.
[90] Przedborski S, Jackson-Lewis V, Djaldetti R, Liberatore G, Vila M, Vukosavic S, \& Almer G (2000) The parkinsonian toxin MPTP: action and mechanism. Restor Neurol Neurosci, 16, 135-142.

[91] Inoue $\mathrm{H}$, Castagnoli $\mathrm{K}$, Van Der Schyf C, Mabic S, Igarashi K, \& Castagnoli N Jr (1999) Species-dependent differences in monoamine oxidase $\mathrm{A}$ and B-catalyzed oxidation of various C4 substituted 1-methy-4-phenyl1,2,3,6-tetrahydropyridinyl derivatives. J Pharmacol Exp Ther, 291, 856-864.

[92] Andersen JK, Frim DM, Isacson O, Beal MF, \& Breakefield XO (1994) Elevation of neuronal MAO-B activity in a transgenic mouse model does not increase sensitivity to the neurotoxin 1-methyl-4-phenyl-1,2,3,6tetrahydropyridine (MPTP). Brain Res, 656, 108-114.

[93] Kilbourn M \& Frey K (1996) Striatal concentrations of vesicular monoamine transporters are identical in MPTPsensitive (C57BL/6) and -insensitive (CD-1) mouse strains. Eur J Pharmacol, 307, 227-232.

[94] Ali SF, David SN, \& Newport GD (1993) Age-related susceptibility to MPTP-induced neurotoxicology in mice. Neurotoxicology, 14, 29-34.

[95] Ali SF, David SN, Newport GD, Cadet JL, \& Slikker W Jr (1994) MPTP-induced oxidative stress and neurotoxicity are age-dependent: evidence from measures of reactive oxygen species and striatal dopamine levels. Synapse 18, 27-34.

[96] Przedborski S, Kostic V, Jackson-Lewis V, Naini AB, Simonetti S, Fahn S, Carlson E, Epstein CJ, \& Cadet JL (1992) Transgenic mice with increased $\mathrm{Cu} / \mathrm{Zn}$-superoxide dismutase activity are resistant to N-methyl-4-phenyl1,2,3,6-tetrahydropyridine-induced neurotoxicity. J Neurosci, 12, 1658-1667.

[97] Andrews AM, Ladenheim B, Epstein CJ, Cadet JL, \& Murphy DL (1996) Transgenic mice with high levels of superoxide dismutase activity are protected from the neurotoxic effects of 2'-NH2-MPTP on serotonergic and noradrenergic nerve terminals. Mol Pharmacol, 50, 15111519.

[98] Andrews AM \& Murphy DL (1993) 2'-NH2-MPTP in Swiss Weber mice: evidence for long-term (6-months) depletions in cortical and hippocampal serotonin and norepinephrine, differential protection by selective uptake inhibitors or clorgyline and functional changes in central serotonin neurotransmission. J Pharmacol Exp Ther, 267, 14321439.

[99] Andrews AM \& Murphy DL (1993) Sustained depletion of cortical and hippocampal serotonin and norepinephrine but not striatal dopamine by 1-methyl-4-(2'-aminophenyl)1,2,3,6-tetrahydropyridine (2'-NH2-MPTP): a comparative study with 2'-CH3-MPTP and MPTP. J Neurochem, 60, 1167-1170.

[100] Gainetdinov RR, Fumagalli F, Jones SR, \& Caron MG (1997) Dopamine transporter is required for in vivo MPTP neurotoxicity: evidence from mice lacking the transporter. J Neurochem, 69, 1322-1325.

[101] Womer DE, Jones BC, \& Erwin VG (1994) Characterization of dopamine transporter and locomotor effects of cocaine, GBR 12909, epidepride, and SCH 23390 in C57BL and DBA mice. Pharmacol Biochem Behav, 48, 327-335.

[102] Hazell AS, Itzhak Y, Liu H, \& Norenberg MD (1997) 1-methyl-4-phenyl-1,2,3,6-tetrahydropyradine (MPTP) decreases glutamate uptake in cultured astrocytes. $J$ Neurochem, 68, 2216-2219.

[103] Kupsch A, Gerlach M, Pupeter SC, Sautterx J, Dirr A, Arnold G, Opitz W, Przuntek H, Riederer P, \& Oertel WH (1995) Pretreatment with nimodipine prevents MPTP- 
induced neurotoxicity at the nigral, but not at the striatal level in mice. Neuroreport, 6, 621-625.

[104] Swerdlow RH, Parks JK, Miller SW, Tuttle JB, Trimmer PA, Sheehan JP, Bennett JP, Davis RE, \& Parker WD Jr (1996) Origin and functional consequences of the complex I defect in Parkinson's disease. Ann Neurol 40, 663671.

[105] Hoskins JA \& Davis LJ (1989) The acute effect on levels of catecholamines and metabolites in the brain of a single dose of MPTP in 8 strains of mice. Neuropharmacology, 28, 1389-1397.

[106] Schwarting RK, Sedelis M, Hofele K, Auburger GW, \& Huston JP (1999) Strain-dependent recovery of open-field behavior and striatal dopamine deficiency in the mouse MPTP model of Parkinson's disease. Neurotox Res, 1 , 41-56.

[107] Hofele K, Sedelis M, Auburger GW, Morgan S, Huston JP, \& Schwarting RKW (2001) Evidence for a dissociation between MPTP toxicity and tyrosinase activity based on congenic mouse strain susceptibility. Exper Neurol 168, $116-122$.

[108] Festing MF (1991) Genetic factors in neurotoxicology and neuropharmacology: a critical evaluation of the use of genetics as a research tool. Experientia, 47, 990-998.

[109] Schapira AH (1993) Mitochondrial complex I deficiency in Parkinson's disease. Adv Neurol, 60, 288-291.

[110] Petroske E, Meredith GE, Callen S, Totterdell S, \& Lau YS (2001) Mouse model of parkinsonism: a comparison between subacute MPTP and chronic MPTP/probenecid treatment. Neuroscience, 106, 589-601.

[111] Meredith GE \& Kang UJ (2006) Behavioral models of Parkinson's disease in rodents: a new look at an old problem. Mov Disord, 21, 1595-1606.

[112] Dauer W \& Przedborski S (2003) Parkinson's disease: Mechanisms and models. Neuron, 39, 889-909.

[113] Dawson TM \& Dawson VL (2003) Molecular pathways of neurodegeneration in Parkinson's disease. Science 302, 819822

[114] Meredith GE, Sonsalla PK, \& Chesselet M-F (2008) Animal models of Parkinson's disease progression. Acta Neuropathol, 115, 385-398.

[115] Hallman H, Lange J, Olson L, Stromberg I, \& Jonsson G (1985) Neurochemical and histochemical characterization of neurotoxic effects of 1-methyl-4-phenyl-1,2,3,6tetrahydropyridine on brain catecholamine neurones in the mouse. J Neurochem, 44, 117-127.

[116] Bezard E, Dovero S, Bioulac B, \& Gross CE (1997) Kinetics of nigral degeneration in a chronic model of MPTP-treated mice. Neurosci Lett, 234, 47-50.

[117] Shimoji M, Zhang L, Mandir AS, Dawson VL, \& Dawson TM (2005) Absence of inclusion body formation in the MPTP mouse model of Parkinson's disease. Brain Res Mol Brain Res, 1345, 103-108.

[118] Tatton NA \& Kish SJ (1997) In situ detection of apoptotic nuclei in the substantia nigra compacta of 1-methyl-4-phenyl-1,2,3,6-tetrahydropyridine-treated mice using terminal deoxynucleotidyl transferase labeling and acridine orange staining. Neuroscience, 77, 1037-1048.

[119] Gibrat C, Saint-Pierre M, Bousquet M, Lévesque D, Rouillard C, \& Cicchetti F (2009) Differences between subacute and chronic MPTP mice models: investigation of dopaminergic neuronal degeneration and alpha-synuclein inclusions. J Neurochem, 109, 1469-1482.

[120] Novikova L, Garris BL, Garris DR, \& Lau YS (2006) Early signs of neuronal apoptosis in the substantia nigra pars com- pacta of the progressive neurodegenerative mouse 1-methyl4-phenyl-1,2,3,6-tetrahydropyridine/probenecid model of Parkinson's disease. Neuroscience, 140, 67-76.

[121] Meredith GE, Totterdell S, Petroske E, Santa Cruz K, Callison RC, \& Lau YS Jr (2002) Lysosomal malfunction accompanies alpha-synuclein aggregation in a progressive mouse model of Parkinson's disease. Brain Res, 956, 156165 .

[122] Xu Z, Cawthon D, McCastlain KA, Slikker W, \& Ali SF $\mathrm{Jr}$ (2005) Selective alterations of gene expression in mice induced by MPTP. Synapse, 55, 45-51.

[123] Goldberg NRS, Haack AK, Lim NS, Janson DK, \& Meshul CK (2011) Dopaminergic and behavioral correlates of progressive lesioning of the nigrostriatal pathway with 1methyl-4-phenyl-1,2,3,6-tetrahydropyridine. Neuroscience, 180, 256-271.

[124] Greenamyre JT \& Hastings TG (2004) Parkinson's divergent causes, convergent mechanisms. Science, 304, 1120-1122.

[125] Barron KD (1995) The microglial cell. A historical review. J Neurol Sci, 134, 57-68.

[126] Block ML, Zecca L, \& Hong JS (2007) Microglia-mediated neurotoxicity: uncovering the molecular mechanisms. Nat Rev Neurosci, 8, 57-69.

[127] Liu B, Du L \& Hong JS (2000) Naloxone protects rat dopaminergic neurons against inflammatory damage through inhibition of microglia activation and superoxide generation. J Pharmacol Exp Ther, 293, 607-617.

[128] McGeer PL, Schwab C, Parent A, \& Doudet D (2003) Presence of reactive microglia in monkey substantia nigra years after 1-methyl-4-phenyl-1,2,3,6-tetrahydropyridine administration. Ann Neurol, 54, 599-604.

[129] Gao HM, Liu B, \& Hong JS (2003) Critical role for microglial NADPH oxidase in rotenone-induced degeneration of dopaminergic neurons. J Neurosci, 23, 6181-6187.

[130] Langston JW, Forno LS, Tetrud J, Reeves AG, Kaplan JA, \& Karluk D (1999) Evidence of active nerve cell degeneration in the substantia nigra of humans years after 1-methyl4-phenyl-1,2,3,6-tetrahydropyridine exposure. Ann Neurol, 46, 598-605.

[131] Kurkowska-Jastrzebska I, Wrónska A, Kohutnicka M, Czlonkowski A, \& Czlonkowski A (1999) The inflammatory reaction following 1-methyl-4-phenyl-1,2,3,6tetrahydropyridine intoxication in mouse. Exp Neurol, 156, 50-61.

[132] Luchtman DW, Shao D, \& Song C (2009) Behavior, neurotransmitters and inflammation in three regimens of the MPTP mouse model of Parkinson's disease. Physiol, 98, 130-138.

[133] Gupta M, Gupta BK, Thomas R, Bruemmer V, Sladek JR, \& Felten DL Jr (1986) Aged mice are more sensitive to 1methyl-4-phenyl-1,2,3,6-tetrahydropyridine treatment than young adults. Neurosci Lett, 70, 326-331.

[134] Cenci MA, Whishaw IQ, \& Schallert T (2002) Animal models of neurological deficits: how relevant is the rat? Nat Rev Neurosci, 3, 574-579.

[135] Arai N, Misugi K, Goshima Y, \& Misu Y (1990) Evaluation of a 1-methyl-4-phenyl-1,2,3,6-tetrahydropyridine- treated C57 black mouse model for parkinsonism. Brain Res, 515, 57-63.

[136] Fredriksson A, Palomo T, \& Archer T (1999) Effects of coadministration of anticonvulsant and putative anticonvulsive agents and sub/suprathreshold doses of L-dopa upon motor behaviour of MPTP-treated mice. J Neural Transm, 106, 889-909. 
[137] Willis GL \& Donnan GA (1987) Histochemical, biochemical and behavioural consequences of MPTP treatment in C-57 black mice. Brain Res, 402, 269-274.

[138] Tomac A, Lindqvist E, Lin LF, Ogren SO, Young D, Hoffer BJ, \& Olson L (1995) Protection and repair of the nigrostriatal dopaminergic system by GDNF in vivo. Nature, 373, 335-339.

[139] Chia LG, Ni DR, Cheng LJ, Kuo JS, Cheng FC, \& Dryhurst G (1996) Effects of 1-methyl-4-phenyl-1,2,3,6tetrahydropyridine and 5,7-dihydroxytryptamine on the locomotor activity and striatal amines in C57BL/6 mice. Neurosci Lett, 218, 67-71.

[140] Rozas G, Guerra MJ, \& Labandeira-Garcia JL (1997) An automated rotarod method for quantitative drug-free evaluation of overall motor deficits in rat models of parkinsonism. Brain Res Protoc, 2, 75-84.

[141] Rozas G \& Labandeira-Garcia JL (1997) Drug-free evaluation of rat models of parkinsonism and nigral grafts using a new automated rotarod test. Brain Res, 749, 188-199.

[142] Whishaw IQ, Li K, Whishaw PA, Gorny B, \& Metz GA (2003) Distinct forelimb and hind limb stepping impairments in unilateral dopamine-depleted rats: use of the rotorod as a method for the qualitative analysis of skilled walking. J Neurosci Methods, 126, 13-23.

[143] Ogawa N, Hirose Y, Ohara S, Ono T, \& Watanabe Y (1985) A simple quantitative bradykinesia test in MPTP-treated mice. Res Commun Chem Pathol Pharmacol, 50, 435-441.

[144] Chan CS, Guzman JN, Ilijic E, Mercer JN, Rick C, Tkatch T, Meredith GE, \& Surmeier DJ (2007) 'Rejuvenation' protects neurons in mouse models of Parkinson's disease. Nature, 447, 1081-1086.

[145] Tillerson JL \& Miller GW (2002) Forced limb-use and recovery following brain injury. Neuroscientist, 8, 574-585.

[146] Blume SR, Cass DK, \& Tseng KY (2009) Stepping test in mice: a reliable approach in determining forelimb akinesia in MPTP-induced parkinsonism. Exp Neurol, 219, 208-211.

[147] Perry TL, Yong VW, Clavier RM, Jones K, Wright JM, Foulks JG, \& Wall RA (1985) Partial protection from the dopaminergic neurotoxin N-methyl-4-phenyl-1,2,3,6tetrahydropyridine by four different antioxidants in the mouse. Neurosci Lett, 60, 109-114.

[148] Tatton WG \& Greenwood CE (1991) Rescue of dying neurons: a new action for deprenyl in MPTP parkinsonism. $J$ Neurosci Res, 30, 666-672.

[149] Thiffault C, Aumont N, Quirion R, \& Poirier J (1995) Effect of MPTP and 1-deprenyl on antioxidant enzymes and lipid peroxidation levels in mouse brain. J Neurochem, 65, 2725 2733.

[150] Kitamura Y, Kakimura J, \& Taniguchi T (2002) Antiparkinsonian drugs and their neuroprotective effects. Biol Pharm Bull, 25, 284-290.

[151] Chao CC, Hu S, Molitor TW, Shaskan EG, \& Peterson PK (1992) Activated microglia mediate neuronal cell injury via a nitric oxide mechanism. J Immunol, 149, 27362741.

[152] Hunot S, Boissière F, Faucheux B, Brugg B, Mouatt-Prigent A, Agid Y, \& Hirsch EC (1996) Nitric oxide synthase and neuronal vulnerability in Parkinson's disease. Neuroscience, 72, 355-363.
[153] Le W, Rowe D, Xie W, Ortiz I, He Y, \& Appel SH (2001) Microglial activation and dopaminergic cell injury: an in vitro model relevant to Parkinson's disease. J Neurosci, 21, 8447-8455.

[154] Breidert T, Callebert J, Heneka MT, Landreth G, Launay JM, \& Hirsch EC (2002) Protective action of the peroxisome proliferator-activated receptor-gamma agonist pioglitazone in a mouse model of Parkinson's disease. J Neurochem, 82, 615-624.

[155] Lin S, Wei X, Xu Y, Yan C, Dodel R, Zhang Y, Liu J, Klaunig JE, Farlow M, \& Du Y (2003) Minocycline blocks 6-hydroxydopamine-ionduced neurotoxicity and free radical production in rat cerebellar granule neurons. Life Sci, 72, 1635-1641.

[156] Du Y, Ma Z, Lin S, Dodel RC, Gao F, Bales KR, Trarhou LC, Chernet E, Perry KW, Nelson DL, Luecke S, Phebus LA, Bymaster FP, \& Paul SM (2001) Minocycline prevents nigrostriatal dopaminergic neurodegeneration in the MPTP model of Parkinson's disease. Proc Natl Acad Sci USA, 98, 14669-14674.

[157] Yang L, Sugama S, Chirichigno JW, Gregorio J, Lorenzl S, Shin DH, Browne SE, Shimizu Y, Joh TH, Beal MF, \& Albers DS (2003) Minocycline enhances MPTP toxicity to dopaminergic neurons. J Neurosci Res, 74, 278-285.

[158] Chan P, Di Monte DA, Langston JW, \& Janson AM (1997) (+)MK-801 does not prevent MPTP-induced loss of nigral neurons in mice. J Pharm Exp Ther, 280, 439-446.

[159] Kupsch A, Löshmann PA, Sauer H, Arnold G, Renner P, Pufal D, Burg M, Wachtel H, ten Bruggencate G, \& Oertel WH (1992) Do NMDA antagonists protect against MPTP toxicity? Biochemical and immunocytochemical analyses in black mice. Brain Res, 592, 74-83.

[160] Santiago M, Venero JL, Machado A, \& Cano J (1992) In vivo protection of striatum from MPP+ neurotoxicity by N-methyl-D-aspartate antagonists. Brain Res, 586, 203-207.

[161] Sonsalla PK, Zeevalk GD, Manzino L, Giovanni A, \& Nicklas WJ (1992) MK-801 fails to protect against the dopaminergic neuropathology produced by systemic 1-methyl-4-phenyl-1,2,3,6-tetrahydropyridine in mice or intranigral 1-methyl-4-phenylpyridinium in rats. $\mathrm{J} \mathrm{Neu}$ rochem, 58, 1979-1982.

[162] Turski L, Bressler K, Rettig KJ, Löschmann PA, \& Wachtel H (1991) Protection of substantia nigra from MPP+ neurotoxicity by N-methyl-D-aspartate antagonists. Nature, $\mathbf{3 4 9}$, 414-418.

[163] Mercuri NB, Bonci A, Calebresi P, Stratta F, Stefani A, \& Bernardi G (1994) Effects of dihydropyridine calcium antagonists on rat midbrain dopaminergic neurones. $\mathrm{Br} \mathrm{J}$ Pharmacol, 113, 831-838.

[164] Nedergaard S, Flatman JA, \& Engberg I (1993) Nifedipineand omega-conotoxin-sensitive $\mathrm{Ca}^{2+}$ conductances in guinea-pig substantia nigra pars compacta neurones. J Physiol, 466, 727-747.

[165] Shepard PD \& Stump D (1999) Nifedipine blocks apamininduced bursting activity in nigral dopamine-containing neurons. Brain Res, 817, 104-109. 